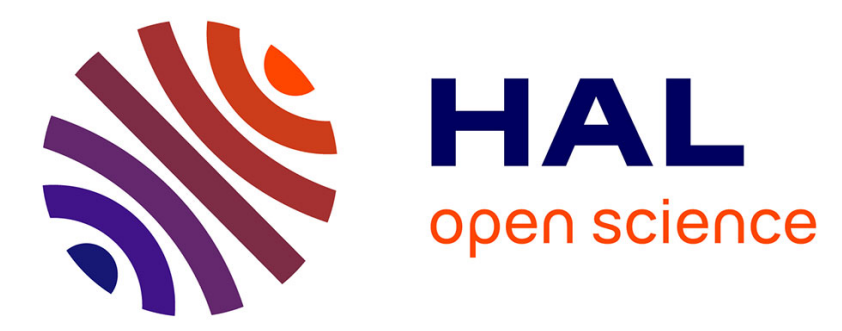

\title{
Building piezometric maps: contribution of geostatistical tools
}

Bernard Bourgine, Nicolas Pedron, Eric Lavie

\section{To cite this version:}

Bernard Bourgine, Nicolas Pedron, Eric Lavie. Building piezometric maps: contribution of geostatistical tools. 10th International Geostatistics Congress, Sep 2016, Valencia, Spain. hal-01301830

\section{HAL Id: hal-01301830 https: / hal-brgm.archives-ouvertes.fr/hal-01301830}

Submitted on 13 Apr 2016

HAL is a multi-disciplinary open access archive for the deposit and dissemination of scientific research documents, whether they are published or not. The documents may come from teaching and research institutions in France or abroad, or from public or private research centers.
L'archive ouverte pluridisciplinaire $\mathbf{H A L}$, est destinée au dépôt et à la diffusion de documents scientifiques de niveau recherche, publiés ou non, émanant des établissements d'enseignement et de recherche français ou étrangers, des laboratoires publics ou privés. 


\title{
Building piezometric maps: contribution of geostatistical tools
}

\author{
Bernard BOURGINE ${ }^{1}$, Nicolas PEDRON ${ }^{1}$ \& Eric LAVIE ${ }^{2}$ \\ ${ }^{1}$ BRGM (French Geological Survey) B.P. 6009 - 45060 Orléans Cedex 2, France - \\ b.bourgine@brgm.fr;n.pedron@brgm.fr \\ ${ }^{2}$ Région Aquitaine - 14 rue François de Sourdis - 33077 Bordeaux - France. e.lavie@aquitaine.fr
}

\begin{abstract}
:
The work presented has been carried out in the framework of an agreement entitled "Groundwater management in Aquitaine Region », signed between BRGM and Aquitaine Region for the 2008-2013 period, and financially supported by the Adour Garonne Water Agency.

This work aims at setting tools and procedures in order to facilitate the production of piezometric maps of the various aquifers of the Aquitanian Basin, using appropriate interpolation technique. The objective is also to propose as repeatable as possible workflows in order to facilitate and standardize the work, from data control to the final map.
\end{abstract}

Thus BRGM tested on two deep aquifers how geostatistical tools could be applied in order to answer to Aquitaine Region demand concerning :

- best practices for the construction of piezometric maps, as a function of available data and hydrogeological context, with computation of error maps, applying standard geostatistical techniques as well as more advanced ones,

- optimisation of piezometer monitoring network,

- production of a report showing how these methods can be applied on some «study cases », to be used by hydrogeologists in charge of building or using piezometric maps and not familiar with geostatistical tools.

Various geostatistical tools were tested and compared on two aquifers (a confined aquifer and an unconfined one) :

- standard (co)kriging including or not a polynomial drift,

- $\quad$ kriging with an external drift based either on the result of an hydrodynamic flow model or on other variables like a smoothed topography,

- co-kriging with partial derivatives in order to take into account boundary conditions and/or hydrogeological constraints like groundwater divide,

- cross-validation procedures to identify anomalous data or to optimize the monitoring network.

Except for kriging with partial derivatives, for which few applications are reported in the literature, this paper presents "standard" geostatistical tools. It shows the interest of introducing more geostatistics in construction of piezometric maps, a domain where geostatistics is less widely used compared to other domains like mineral industry. Consecutive to this study the Department of Gironde (main Department of Aquitaine Region) started producing annual piezometric maps using geostatistical techniques. These maps and their associated kriging standard deviation are built using external drift kriging and are delivered on their web site. Geostatistics can help hydrogeologist to produce piezometric maps, but expertise of the hydrogeologist is essential to introduce appropriate calculation parameters and to validate the result.

\section{Keywords:}

Piezometric maps, kriging with partial derivatives, boundary conditions 